\title{
A GRAÇA E A SIMPLICIDADE DAS CARTAS NO TRATADO SOBRE O ESTILO DE DEMÉTRIO ${ }^{\star}$
}

\author{
Gustavo Araújo de Freitas ${ }^{\star \star}$ \\ Faculdade de Letras da Universidade Federal de Minas Gerais
}

RESUMÉ: Au-dessus d'autres discours, la lettre révèle, avec sa simplicité, le caractère de son auteur; elle est une brève démonstration d'amitié; "l'image de l'âme", nous avait dit Démétrios. Le traité $D u$ style est le premier document, parmi les traités de rhétorique, avec un plus long développement sur cette question, et, en fait, cet excursus est très célèbre. Cependant, nous pouvons discuter beaucoup de choses liés à l'éducation rhétorique ou au propre traité, y compris les deux aspects que l'auteur recommande: grâce et humour. Ainsi, cet article a le but de présenter quelques éléments de cet excursus du traité $D u$ style de Démétrios, en vue, surtout, de sa critique littéraire.

MOTS-CLÉS: Épistolographie; Démétrios; Du style; critique littéraire; rhétorique.

\footnotetext{
* O presente trabalho foi realizado com apoio do CNPq, Conselho Nacional de Desenvolvimento Científico e Tecnológico - Brasil, e concebido a partir da dissertação de mestrado defendida pelo autor no $1^{\circ}$ semestre de 2011, pelo Programa de Pós-Graduação em Estudos Literários, na área de concentração de Estudos Clássicos da Faculdade de Letras da UFMG, intitulada "Sobre o estilo" de Demétrio: um olhar crítico sobre a literatura grega (tradução e estudo introdutório do tratado), sob a orientação do Prof. Dr. Jacyntho José Lins Brandão.

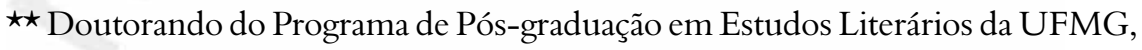
da área de concentração: Literaturas Clássicas e Medievais.

$\star \star \star$ garafreitas@hotmail.com
} 
uitas controvérsias ainda rondam o tratado Sobre o estilo (Perì Hermèneías) de Demétrio, mas, há, atualmente, uma tendência entre os estudiosos a considerá-lo como um manual de retórica inserido no contexto da educação vigente no período helenístico, situando-o por volta do séc. I a.C. ${ }^{1}$ Nesse contexto, então, justifica-se a imbricada relação da retórica com a crítica literária. ${ }^{2}$

E se, por um lado, a obra não nos fornece informações muito precisas quanto a seu público, por outro, é evidente a presença de uma relação professor-aluno na base de sua composição. ${ }^{3}$ Mais ainda, por meio de inferências, Schenkeveld ${ }^{4}$ aponta para a existência de um público de leitores

${ }^{1}$ Entre os estudiosos mais recentes que propuseram essa datação ou uma aproximada: cf. Chiron, 2001; Chiron, 1993; Innes, 2005; Schenkeveld, 2000, p. 29-48. Se seria um manual de retórica ou uma obra de crítica literária, Innes chega a afirmar que, à diferença de muitas outras fontes, particularmente em latim, não haveria nele uma propensão para a oratória (2005, p. 312). Grube, sem que, de fato, desconsidere a vinculação do tratado à retórica, em dado momento, comenta que o interesse de Demétrio seria pela literatura, mais do que pelos processos, casos ou argumentos ligados aos tribunais (Grube, 1995, p. 119). Em outra ocasião, o mesmo autor volta a salientar que os interesses de Demétrio são obviamente literários, mais do que retóricos no sentido estrito, e lembra que os oradores são frequentemente mencionados, mas apenas como um tipo de literatura dentre vários (1961, p. 22). Kennedy comenta que além das lições de como se escrever bem, o $P H$ é também uma sensível peça de crítica literária (1999, p. 131). Schenkeveld defende, no entanto, a ideia de que o tratado de Demétrio tenha, de fato, sido um manual de retórica (1964, p. 51-52), e, ao certo, é mesmo dele a melhor resposta para a questão, no artigo mencionado antes. Nessa ocasião, o autor situa a obra no contexto educacional do período helenístico, em uma fase do aprendizado em que a crítica literária não apenas se faz presente como se coloca a serviço da própria retórica (cf. infra). Cf. ainda Chiron, 2001, p. 134.

${ }^{2}$ Classen chega a pôr em xeque a própria existência de limite entre elas, e chama ainda a atenção para o fato de Demétrio demonstrar um dom pela apreciação literária e um gosto altamente desenvolvido, de modo que um trabalho como o seu não poderia ser facilmente substituído, e, por essa razão, diferentemente de muitos manuais comuns, ele foi preservado, com um nome famoso a ele ligado e que lhe conferiu uma proteção adicional (1995, p. 527).

${ }^{3}$ Cf. Schenkeveld, 2000, p. 35-38; cf. ainda Schenkeveld, 1964, p. 51.

${ }^{4}$ Ao certo, Schenkeveld se pauta em um sistema educacional, que, conforme lembraram Marrou e Bompaire, teve pouca variação desde a época de Alexandre e também não apresenta diferenças significativas entre Grécia e Roma (Bompaire, 
que já teriam completado cursos de gramática ${ }^{5}$ e que também já teriam passado pelos cursos iniciais de retórica, onde teriam estudado e praticado os progymnásmata, e lido e decorado várias passagens famosas de autores da prosa. ${ }^{6}$ Assim, estariam em uma nova fase do aprendizado, em que partiriam para lições mais difíceis, comumente chamadas de declamationes. ${ }^{7}$

Logo, não se trata de uma crítica literária no sentido estrito, mas de uma associação entre a mesma e a instrução retórica; nesse quadro, aquela acompanha conselhos de ordem prática, além, é claro, de situações de enunciação para o treinamento de futuros oradores. Assim, justifica-se ainda o grande interesse de Demétrio pelos mais variados tipos de discurso, sejam eles em verso ou em prosa, não obstante as considerações a esta última serem mais recorrentes.

E é também, nesse contexto, que se insere uma das passagens mais conhecidas do $P H$ : o seu excursus sobre a epistolografia, um dos raros registros gregos que trazem uma maior reflexão crítica sobre o gênero epistolar na Antiguidade. E, mais ainda, no âmbito de um desenvolvimento teórico mais amplo em que se torna difícil dissociar a crítica literária da referida função retórica, sobretudo, quando se trata de textos em prosa,

2000, p. 35; Marrou, 1975, p. 153). Acerca do ensino literário no período em questão, cf. ainda Bompaire, 2000, p. 33-97.

${ }^{5}$ Acerca dos níveis educacionais, cf. Marrou, 1975, p. 251: A cada um dos três graus, primário, secundário e superior, corresponde, para o ensino das letras, um mestre especializado: ao instrutor primário ("grammatistés") sucede o 'gramático' ("grammatikós") e a este o retórico, "sophistés" ou "rhétôr". Ao certo, Stowers problematiza essa questão (1986, p. 32; cf. infra).

${ }^{6}$ Cf. Schenkeveld, 2000, p. 40. Nesse ponto, parece oportuno lembrar o debate levantado por Innes, que contesta o autor por este ter afirmado que Demétrio teria sido um escritor de um manual de estilística para futuros oradores ("orators-tobe"). A autora teria questionado por que haveria matérias não propriamente de oratória ("non-oratorical") no caso do estilo grandioso, como as batalhas navais (\$75), e tão poucos exemplos da oratória no $P H$ (Reviewed work(s): studies in Demetrius "On style" by Dirk Marie Schenkeveld. The classical review, new series, Cambridge, vol. XVI, n. 3, p. 315-317, dec. 1966, p. 316). O autor se defende, contudo, dizendo que, na ocasião da publicação de seu livro (1964, p. 80), de fato não esclarecera quem seriam esses 'futuros oradores', o que, pelo que diz em seu artigo, não só se torna mais nítido, como também justifica a consequente presença de assuntos não propriamente ligados à oratória.

${ }^{7}$ Cf. Schenkeveld, 2000, p. 47. Uma consequência dessa suposição, conforme salienta o autor, é que precisamos supor que a restrição das declamationes aos assuntos ligados ao discurso forenses e deliberativos ainda não tivesse ocorrido. 
este excursus se notabiliza por seu enfoque amplamente literário.

\section{O excursus no contexto da crítica literária à prosa no $P H$}

Em razão da própria ênfase dada à instrução oratória, é natural que a crítica literária aos textos em prosa se faça mais presente no tratado, porém, para efeito de análise, isso acarreta uma maior dificuldade em desvincular tal crítica da função desse manual, tendo ainda como obstáculo o fato de que o seu autor não define claramente os limites do discurso retórico, conforme podemos constatar pela própria terminologia aplicada.

O termo lógos - a despeito de alguns momentos, em que também se aplica a textos em verso - , em geral, define a prosa, apresentando um expressivo número de ocorrências e aplicando-se a uma considerável gama de exemplos. Tais exemplos incluem trechos extraídos de obras de historiadores, como Tucídides, Heródoto, Xenofonte; de filósofos, como Platão e Aristóteles; além, é claro, de oradores, como Górgias, Demóstenes, Isócrates, Lísias, Dêmades. Temos, ainda, citações retiradas de mimos, correspondências, provérbios, máximas, entre outros.

Mas há termos que, em dadas circunstâncias, aplicam-se de forma específica à oratória: rhētoreía (oratória, retórica), rhētorikós (oratório, retórico) e rhêtōr (orador, retor). Contudo, suas ocorrências não indicam, necessariamente, uma tentativa de distingui-la dos demais discursos, como aquela que se observa, por exemplo, da poesia com relação à prosa. ${ }^{8}$ Ao contrário, o termo lógos (e derivados), com bastante frequência, faz menção à oratória. ${ }^{9}$

\footnotetext{
${ }^{8}$ Acerca dessa análise terminológica, poesia versus prosa, cf. de Freitas, 2011, p. 26-30.

${ }^{9}$ No parágrafo 12, por exemplo, o termo rhètoreía define a oratória de Isócrates, Górgias e Alcidamante; contudo, no parágrafo 15, para referir-se ao discurso de Górgias, Demétrio emprega o termo lógos, e, nos parágrafos 68 e 299, o mesmo refere-se ao discurso de Isócrates; inclusive, neste segundo caso, o exemplo do discurso veemente (deinòs lógos), tomado como contraponto ao de Isócrates, é, justo, uma citação de Demóstenes. Ademais, o termo rhếtōr, pelo menos em duas oportunidades, nos parágrafos 24 e 287, denota um tom depreciativo, e o mesmo se verifica no emprego de rhētoreía, no parágrafo 9. Mas, de fato, não significa que esses termos, em todas as suas ocorrências, sejam imbuídos desse caráter depreciativo: as outras duas ocorrências de rhêtōr , nos parágrafos 262 e 275, não demonstram, pois, o mesmo tom, tampouco a outra passagem de rhētoreía, no parágrafo 12 , acima mencionado. De qualquer modo, tais ocorrências não deixam de revelar
} 
Em outras palavras, ainda que se identifique a presença de uma terminologia específica da oratória, não se pode afirmar que estejam estabelecidos, propriamente, os limites desse discurso. Isto é, o lógos, a par da distinção que ocorre com relação à poesia, engloba, indistintamente, os mais diferentes tipos de discurso. E isso implica que a reflexão crítica sobre os mesmos - e, nesse ponto, referimo-nos, de fato, à crítica literária —, em certa medida, confunde-se ainda mais com conselhos de ordem prática ao orador, tendo vista a construção do discurso.

Quando analisamos as ocorrências relacionadas à poesia, por exemplo, constatamos um grande interesse pelo que haveria nela de mais específico; por conseguinte, ao distanciar-se do que seria mais precisamente o discurso em prosa, a reflexão crítica afasta-se também, um pouco mais, daquela referida função do manual, sendo possível identificar com maior nitidez a crítica literária. Já os limites entre a oratória e os demais discursos em prosa são demasiado tênues para que possamos ter a mesma percepção.

Além disso, se atentarmos para as citações extraídas da prosa presentes no $P H$, veremos que aquelas de autores reconhecidos na tradição como ligados, mais especificamente, à oratória, além de se encontrarem em menor número, concentram-se, em especial, naquele capítulo destinado à veemência (deinótēs). ${ }^{10}$ Logo, com relação aos outros três tipos de estilo, o grandioso (megaloprepés), o elegante (glaphyrós) e o simples (iskhnós), a presença dos oradores é discreta, enquanto, no capítulo destinado à veemência (deinótés), o principal modelo é Demóstenes.

que esses termos não parecem estar na preferência de Demétrio, quando se trata da oratória, ou, pelo menos, 'daquela' que o autor tanto preza.

${ }^{10}$ No primeiro capítulo, o autor mais citado, como vimos, é Homero; mas, dentre aqueles considerados como próprios da prosa, o maior número de citações vem de Tucídides. Esse é citado em onze oportunidades, enquanto Isócrates, juntamente com Xenofonte, em outras cinco, cada um, Platão, em quatro, Górgias e Heródoto em duas, e temos, ainda, uma citação de Antifonte e a ameaça do tirano de Siracusa, Dionísio, além de uma citação de Demóstenes. Quanto àquelas referentes ao estilo elegante, como também vimos, Safo, dentre todos os autores, é quem fornece o maior número de citações, sendo oito no total. Xenofonte viria, então, em segundo lugar, com sete, seguido de Sófron e Homero, com cinco, Platão e Aristóteles, com quatro, cada um, Aristófanes, com três, Lísias, com duas, e, ainda, com uma, Crates, Dicearco, Ésquines, Heródoto, Menandro e Demóstenes. Já referentes ao estilo simples, teríamos quatro citações de Aristóteles, três de Homero, duas de Ctésias, duas de Platão, uma de Lísias e uma de Tucídides. Para um exame dessas menções e de sua distribuição ao longo do desenvolvimento sobre os tipos de estilo, cf. ainda Chiron, 2001, p. 389. 
O orador ático que serve de parâmetro para toda a discussão sobre o estilo veemente (deinós) - e que fora citado apenas em quatro ocasiões na introdução, uma no primeiro capítulo e outra no segundo,$-{ }^{11}$ na ocasião daquele último, é, pois, mencionado em quinze oportunidades, um número expressivamente maior se comparado não só às outras menções que lhe foram feitas ao longo do $P H$, mas também às dos demais autores neste capítulo. ${ }^{12}$

Conquanto valha destacar que, em vista dessa evidente relação que se estabelece entre a deinótes e o discurso oratório, ou pelo menos, o de Demóstenes, não se deve inferir que o autor do $P H$ esteja propondo, de fato, uma cisão entre esse discurso e os demais. Primeiro porque o próprio ensinamento dos oradores compreende a leitura das mais diversas formas de discurso, isto é, não é porque Demétrio trate menos da oratória, em específico, que essa não seja o seu principal objetivo final. Depois, porque, sem que se desconsidere o foco do tratado, há um patente interesse em discorrer sobre todas as formas de discurso, ou, mais do que isso, sem uma preocupação maior em delimitar tais formas.

Em outras palavras, embora Demétrio tenha, de fato, uma percepção acerca de suas diferenças, ele opta, salvo algumas ocasiões, por desconsiderá-las, o que propicia, justamente, uma maior proximidade entre os mais diversos discursos, vistos, então, sob um enfoque mais amplo e definidos por um termo mais genérico. E, assim, não se nota, na maior parte das vezes, uma separação nítida entre os discursos mais especificamente ligados à oratória e os demais, sejam eles referentes à historiografia, aos diálogos filosóficos, ao teatro, ao endereçamento aos poderosos, ao modo cínico, sejam outros tantos. ${ }^{13} \mathrm{E}$, então, não surpreende, de todo, que a

${ }^{11}$ É oportuno ressaltar que essas menções não lhe atribuem aspectos de algum "tipo de estilo" (kharaktér hērmēneías) em específico, à exceção do $\ 181$, em que se admite uma aproximação com o estilo elegante (glaphyrós), mas que, de fato, reflete uma situação excepcional ressaltada pelo próprio Demétrio. Ao certo, aquelas dos \10, 11 e 20, aproximam-no da oratória, em especial, mas no âmbito daquela oposição entre os três tipos de períodos: "retórico", "dialógico" e "histórico". Por fim, a do \ 31 serve de exemplo para a distinção entre período e entimema.

${ }^{12}$ Quatro de Dêmades, três de Homero e Platão, duas de Diógenes, Ésquines (orador) e Hipônax, e uma de Antístenes, Lísias, Xenofonte, Ctésias, Dicearco e Ésquines (socrático).

${ }^{13}$ Cf. Chiron, 2001, p. 133: En realité, les liens entre les types de styles et les genres oratoires n'est jamais simple ni univoque (...). Mais surtout (...) l'ouvrage est rempli de préceptes valables pour d'autres espèces d'exercice de la parole ou de la communication en général: l'historiographie (\$19), le dialogue (\$21), la lettre (\$223sq.), peut-être le Roman (\$212 
epistolografia possa estar também entre esses, tampouco o fato de que seja ela também devidamente tratada como um lógos. ${ }^{14}$

Mas, sem dúvida, se a questão da crítica literária à prosa, em especial, como vimos, resta indissociável das lições deste manual, sendo ainda mais difícil de ser detectada em separado, nesse excursus, em particular, a presença dela pode ser detectada com uma nitidez relativamente maior; não que a referida instrução não sirva de pano de fundo, mas, observa-se, nesse caso, que a relação com a oratória, propriamente dita, não vem a ser tão decisiva, e, por conseguinte, a crítica literária passa a ser, de algum modo, ainda mais preponderante.

\section{A epistolografia no $\mathrm{PH}$ e o quadro educacional do período helenístico}

Conforme lembra Stowers, o ensino relacionado à escrita de cartas enquadrar-se-ia no sistema educacional do período helenístico, "conquanto não saibamos quão ampla essa instrução era ou exatamente o que era ensinado". ${ }^{15}$ Ao certo, o autor tece importantes ponderações quanto ao esquema tradicionalmente aceito para tal sistema, em vista das diferenças regionais e socioculturais; de qualquer modo, em linhas gerais, considerando os três estágios de instrução tradicionalmente concebidos pelos estudiosos — o do instrutor primário (grammatistés), o do secundário (grammatikós) e, por fim, aquele do rhêtōr - ${ }^{16}$ ela seria, conforme o teórico, ensinada no segundo estágio da educação. Nessa etapa, destacar-se-iam os "os exercícios elementares de retórica (progymnásmata)", os quais teriam sido "ensinados nos vários níveis da educação secundária, embora os retóricos estivessem inclinados a deixar para o gramático nada mais do que exercícios elementares". ${ }^{17}$

Stowers se baseia, principalmente, nos tratados sobre progymnásmata, de Aelius Théon e Nicolau, nos quais encontramos referências à escrita de cartas como parte do curso, centrada na discussão acerca do caráter do remetente e do destinatário. ${ }^{18} \mathrm{E}$, ao certo, isso estaria relacionado, segundo

sq.), les remontrances aux puissants (\$289sq), le style "scénique” (\$193sq), etc.

${ }^{14}$ Cf. $₫ 227$.

${ }^{15}$ Cf. Stowers, 1986, p. 32.

${ }^{16}$ Cf. Marrou, 1975, p. 153; cf. supra.

${ }^{17}$ Cf. Stowers, 1986, p. 32.

${ }^{18}$ Cf. Stowers, 1986, p. 32-33; Schenkeveld, 2000, p. 45. 
Schenkeveld, com a formação do jovem para a vida cívica, o que, assim, justificaria a própria presença desse excursus no manual de Demétrio:

É a única lógica para o treino dessa matéria como parte do programa de treinamento como um todo, porque a educação retórica pretende preparar os jovens para cumprirem um papel útil em suas cidades e na vida em geral. É verdade que Demétrio não o diz explicitamente, mas minha interpretação concernente à presença de uma teoria da escrita de cartas nessa obra corresponde a uma visão geral para fins de educação retórica. ${ }^{19}$

Sem dúvida, os elementos vinculados à instrução retórica, levantados pelo estudioso, constituiriam um forte argumento para justificar a inserção de um excursus como esse no $\mathrm{PH}$, mas podemos ir ainda além. Comparado, pois, com outras fontes de informação sobre a epistolografia na Antiguidade, segundo as quais, como advertiu Stowers, "a escrita de cartas foi ensinada pela imitação de modelos ao invés de por meio de uma teoria e regras compreendidas", ${ }^{20}$ em lugar de uma diretriz mais pragmática, prevalece, na passagem de Demétrio, uma reflexão crítico-teórica.

E dentre aquelas fontes, podemos tomar como exemplo o próprio Týpoi epistolikoí (Tipos Epistolares), atribuído a um autor também denominado Demétrio e, muitas vezes, confundido com o mesmo do $P H,{ }^{21}$ mas que, no entanto, como atenta Chiron, provavelmente, deva a atribuição, em particular, a uma aproximação fortuita com a passagem de que aqui tratamos. ${ }^{22}$

De La Torre rememora que essa obra, que trata de vinte e um tipos de carta, sendo o primeiro epistolário conservado, teria tido, então, uma grande influência em obras posteriores, ainda que possamos afirmar que coleções desse tipo tenham circulado bastante na Antiguidade e que a composição de cartas tenha sido um exercício de escola frequente. ${ }^{23}$ Mas, há de se ressaltar, antes de tudo, que um manual como esse, conforme

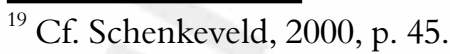

${ }^{20}$ Cf. Stowers, 1986, p. 33.

${ }^{21}$ Cf. De La Torre, La epistolografía griega, p. 33. Acerca desse pequeno manual, cf. ainda Stowers, 1986, p. 51-60.

${ }^{22}$ Cf. Chiron, 1993, p. XCVI.

${ }^{23}$ Cf. De la Torre, La epistolografía griega, p. 33. Cf. ainda Chiron, 1993, p. XCVI: Ensuite, les témoignages se multiplient, mais ils appartiennent à une époque beaucoup plus tardive, tels ceux d'Apollonios de Tyane, de Philostrate de Lemnos, de Gregoire de Nazianze et, bien sûr, des Byzantins.
} 
Chiron salientou, apresenta um caráter "puramente utilitário" e não se ocupa, em momento algum, do aspecto literário da carta, como o excursus do $P H$ o faz. ${ }^{24}$

Logo, parece razoável pensar que, na composição desse excursus, esteja pressuposto um certo conhecimento prévio da parte de um público já iniciado em lições mais práticas - e que poderiam ser, até mesmo, aquelas referentes aos progymnásmata —, e que, por isso, possibilitaria uma reflexão crítica mais elaborada, a qual, como vimos, estaria relacionada, principalmente, com o último estágio da aprendizagem.

Mas, sem dúvida, dificulta o nosso argumento a excepcionalidade dessa teoria no contexto da epistolografia na Antiguidade. Afinal, estamos diante de um dos raros documentos gregos que trazem uma reflexão crítica sobre o gênero, conforme é comentado por vários estudiosos.

Kennedy, por exemplo, destaca que a discussão reflete o crescente papel da carta, pública ou privada, literária ou não literária, no período helenístico, ${ }^{25}$ mas que, apesar de ser uma prática usual, ficou à margem da teoria retórica da Antiguidade, sendo justamente Demétrio quem oferece o primeiro texto conservado sobre a questão. ${ }^{26}$ Em consonância, Chiron destaca que não encontramos nos tratados de retórica, quase nenhum traço dessa teoria sobre o gênero epistolar, somente em passagens isoladas de alguns deles ou nas próprias cartas, notadamente aquelas de Aristóteles. Logo, Demétrio representaria uma exceção, oferecendo um desenvolvimento relativamente longo sobre a mesma. ${ }^{27}$ Grube acrescenta

${ }^{24}$ Cf. Chiron, 1993, p. XCVI.

${ }^{25}$ Cf. Kennedy, 1994, p. 89.

${ }^{26}$ Cf. Kennedy, 1999, p. 131. O comentador destaca, ainda, a existência de coleções de modelos de cartas, das quais sobreviveram fragmentos em papiro, além de haver poucos manuais breves de epistolografia grega, identificando tipos de cartas com exemplos, as quais, no entanto, para a retórica, parecem não ter merecido maior atenção, pelo menos, até a Idade Média.

${ }^{27}$ Cf. Chiron, 1993, p. XCV; Stowers, 1986, p. 34: Letter writing remained only on the fringes of formal rhetorical education throughout antiquity. It was never integrated into the rhetorical systems and thus not appear in the standard hand-books. This means there were never any detailed systematic rules for letters, as there were for standard rhetorical forms. (...). The earliest extant rhetorical work that treats letter writing is the book "On Style". Acerca dessas passagens, De La Torre destaca: La epistolografía griega estuvo pronto acompañada de una interesante preceptiva, muy cercana en sus orientaciones, como es natural, a la que se aplicaba a otras obras literarias y géneros, especialmente la Retórica. Cualquier lector de los epistológrafos griegos repasará con todo gusto las opiniones que sobre esta preceptiva se nos han transmitido bajo los nombres de Demetrio, Proclo, Filóstrato, Gregorio de Nazianzo 
que essa primeira discussão sobre a epistolografia nos textos antigos tem um importância histórica considerável, uma vez que os princípios que expressa encontram ressonância em todas as teorias posteriores sobre a epistolografia. ${ }^{28}$

Seja como for, ainda que, em razão dessa excepcionalidade, não tenhamos parâmetro de comparação, é notório que, sob o ponto de vista de um propósito didático, estejamos perante uma reflexão que vai muito além da pura exposição de modelos a serem imitados, o que nos remeteria para um público em uma fase mais avançada da instrução retórica, onde a crítica literária faz-se mais presente.

\section{Uma mescla de graça e simplicidade, a epistolografia no âmbito do $\mathbf{P H}$}

Ao certo, a par de toda essa tentativa de contextualização, não podemos nos esquecer de que a epistolografia também não é descolada do plano do desenvolvimento teórico do tratado, uma vez que a reflexão sobre o "tipo epistolar" (epistolikòs kharaktếr), nos parágrafos 223 a 235, insere-se no capítulo referente ao "estilo simples" (iskhnós), ao qual a sua vinculação justifica-se, logo, no parágrafo que introduz a discussão: "E uma vez que também o tipo epistolar requer simplicidade, também a seu respeito falaremos" (Epeì dè kaì ho epistolikòs kharaktè̀r deîtai iskhnótētos, kaì perì autôu léxomen). ${ }^{29}$ Com efeito, é

y Focio, a lo que podemos añadir las que se espigan en Mitrídates, Diógenes, Isócrates, Sinesio y otros. No está de más tampoco citar el escólio a Aristófanes ("Plut." 322) en que se

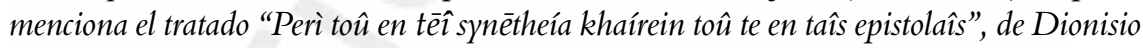
de Alejandría (s. 1 d.J. C.); también muestra interés por el tema Apolonio Díscolo (s. 11 d. J. C.) en el "Perì syntáxeōs". Asimismo en lengua latina tenemos importantes obras de esta indole, como la de Julio Víctor, aparte de las propias opiniones de los epistológrafos latinos (La epistolografía griega, p. 31). Chiron (1993, p. XCV) cita ainda: Cícero, De Oratore, II, 12, 49; Quintiliano, Inst. Or., IX, 4, 19-20; os tratados tardios contendo "exercícios preparatórios" (progymnásmata) que abrangem diretivas sobre as cartas (cf. Théon, II, 115, 22 Spengel; Nicolaos, p. 67 Feleten).

${ }^{28}$ Cf. Grube, 1995, p. 28.

${ }^{29}$ Todas as traduções referentes às passagens do $P H$ são de responsabilidade nossa. Acerca do termo kharaktếr, cf. Chiron, 2001, p. 119-131: Le mot "kharaktếr" s'applique également au style épistolaire (\$223 sq.), comme si la typologie de Démétrios était contaminée par la théorie de genres. Mais à la fin du développement sur la lettre, Démétrios (...) relie le style épistolaire aux principes declarés ici en prescrivant por ce style le melange ("memíkhthō")du style simple et du style élégant. 
oportuno que redirecionemos o foco de nossa análise, mais precisamente, para a inserção desse excursus no âmbito da discussão presente no $P H$.

Sendo assim, ainda no início de sua exposição, Demétrio menciona a enigmática figura de Ártemon, o qual teria sido editor das cartas de Aristóteles. Segundo De La Torre, a primeira coleção de correspondências privadas que se publicou parece ter sido a de Aristóteles, organizada por esse editor. ${ }^{30}$ Além disso, Chiron levanta a hipótese de que Ártemon poderia ter sido um dos primeiros a ter enunciado regras, provavelmente na introdução da coleção citada, embora Demétrio não diga muito de sua teoria, apenas apresente sua definição da carta como uma das duas partes do diálogo. ${ }^{31}$

Pois bem, ao indicar a opinião de Ártemon, Demétrio a aceita, mas não sem ressalva, conforme se lê nos parágrafos 223 e 224:

Ártemon, o editor das cartas de Aristóteles, disse que se deve, do mesmo modo, escrever diálogo e cartas, pois a carta deve ser como uma das duas partes do diálogo. Talvez tenha razão, mas não totalmente. A carta deve de algum modo ser mais elaborada do que o diálogo. Esse imita uma fala improvisada; já ela é escrita e enviada, de certa maneira, como um presente.

Como se nota, o autor utiliza a frase de Ártemon para contraporse a ela e, ao mesmo tempo, definir a especificidade da carta. De fato, poderíamos, em certa medida, identificar os primeiros traços de uma postura antifilosófica com relação à epistolografia, haja vista a importância do diálogo para a atividade do pensamento dos filósofos gregos, o que fora comentado também oportunamente por Chiron, ${ }^{32}$ e que estaria refletido, de algum modo, na concepção de alguém que, afinal, editara cartas de um filósofo.

Mas, além disso, a citação de Ártemon, ao introduzir as reflexões sobre a epistolografia, remete-nos, de imediato, ao autor mais influente na passagem em questão: Aristóteles. Para se ter uma noção dessa influência, o estagirita é mencionado em cinco dos doze parágrafos, sendo que, no parágrafo 230, ele chega a ser considerado o "mais bem sucedido no gênero epistolar" (hòs málista epiteteukhénai dokê̂ tôิ [autô̂] epistolikô̂). ${ }^{33}$

\footnotetext{
${ }^{30}$ Cf. De la Torre, La epistolografía griega, p. 24.

${ }^{31}$ Cf. Chiron, 1993, p. XCV. Conforme lembra o autor, a mesma opinião pode ser verificada, no início da época bizantina, no Epistolimaîoi kharaktéres (1993, p. XCVI).

${ }^{32}$ Cf. Chiron, 1993, p. XCVI.

${ }^{33}$ Cf. $\ 223,225,230,233,234$.
} 
A propósito, não deixa de ser curioso o fato de o filósofo ter sido tomado como principal modelo em uma passagem onde prevalece, justamente, uma postura antifilosófica. Além do que, vem a ser surpreendente a indicação da presença de elementos na obra do peripatético, tais como a simplicidade amistosa no assunto e nas palavras, incomuns, se levarmos em conta seus textos filosóficos mais conhecidos. Aliás, é oportuno salientar que o próprio caráter filosófico de suas cartas a Alexandre é alvo de censura do crítico do $\mathrm{PH}$, para quem o seu estilo elevado aproximá-las-ia, a exemplo do que ocorre com a carta VII de Platão, de verdadeiros tratados, fugindo à essência da epistolografia. ${ }^{34}$

Ainda entremeado nessa discussão, há um breve, mas oportuno, comentário a respeito da diferença entre a linguagem falada e escrita. Ele se encontra no parágrafo 226, em que se discute o fato de não convir à carta o uso das frequentes disjunções (lýseis) apropriadas ao diálogo:

Disjunções frequentes, como as do diálogo, também não são convenientes em cartas. Pois, na escrita, a disjunção acarreta falta de clareza, e seu caráter mimético não é familiar à escrita como o é ao debate; como no Eutidemo: Quem era, Sócrates, aquele com quem dialogava ontem, no Liceu? Sem dúvida, havia muita gente ao redor de vocês. E, um pouco adiante, acrescenta: Mas, a mim, parece ser um estrangeiro aquele com quem você dialogava. Quem era? Toda essa forma de expressar-se e de imitar seria mais conveniente a um ator, não a cartas, que são escritas.

$\mathrm{Na}$ passagem, nota-se com maior clareza a postura antifilosófica de Demétrio no tocante à epistolografia, revelada, assim, na expressa oposição entre ela e o diálogo socrático. Mas, além disso, observa-se que tal oposição estende-se, além do teatro, ao debate, ${ }^{35}$ o que, em alguma medida, poderia refletir a pouca, ou nenhuma, preocupação por parte do autor do $P H \mathrm{em}$ apontar alguma importância da epistolografia para a oratória.

Aliás, em toda a passagem que discorre sobre as cartas, o que se vê é uma reflexão em torno de um gênero essencialmente literário, e que apenas se justifica pela tendência à reflexão crítica acerca da literatura no tratado, mais do que para a oratória propriamente dita.

Contudo, não apenas a diferença com relação ao diálogo é destacada.

\footnotetext{
${ }^{34}$ Cf. $₫ 234$.
}

${ }^{35}$ A aproximação entre o teatro e debate retoma, ao certo, a discussão dos parágrafos 193 e 194. É também interessante notar, na passagem, a aproximação dos mesmos com o diálogo socrático. 
No parágrafo 227, Demétrio aponta para a semelhança, tendo em vista a expressão do caráter (tò èthikón):

Mas que a carta tenha, ao máximo, uma mostra do caráter, tal como o diálogo. Pois cada qual escreve uma carta quase como uma imagem de sua alma. É, de fato, possível notar o caráter do escritor em qualquer discurso, porém em nenhum outro como na carta.

E é também nessa passagem que se encontra outra característica marcante da parte do $\mathrm{PH}$ dedicada à epistolografia: a bela menção à carta como "imagem da alma" (eikòn tēs psŷkhēs). Chiron oportunamente lembra que a carta e, em geral, o estilo enquanto "espelho" ou "imagem" da alma é um motivo muito frequente na literatura epistolográfica ou, simplesmente, na literatura, desde a Antiguidade. ${ }^{36}$ Nesse caso, haveria a presença de três constantes, quaisquer que sejam as variações que a sensibilidade própria de cada época possa vir a ter: simplicidade, verdade e calor humano - que, se Demétrio é o inventor da fórmula, atesta sua influência, ao menos, sobre as mais célebres Correspondências latinas, aquelas de Cícero e Sêneca, notadamente. ${ }^{37}$

De fato, os apontamentos do autor do $\mathrm{PH}$ convergem para uma perspectiva da carta como uma "mostra de amizade" (philophrónēsis), conforme se lê no parágrafo 231:

Essa [a carta] tem por intenção ser uma breve mostra de amizade e uma exposição sobre algum assunto simples e com palavras simples.

Acerca das cartas de amizade (philikaî), Stowers comenta ainda que a discussão de Demétrio refletiria "tradições e convenções bem desenvolvidas acerca da carta enquanto uma expressão da amizade grega”. O autor recorda que elas constituíram um tipo importante de correspondência na Antiguidade, cuja função fundamental e própria os teóricos e escritores educados na tradição epistolar grega presumiam ser a manutenção da amizade. Como oportunamente recorda, "tradições antigas e provérbios (cf. Aristóteles, Ética a Nicômaco 9.8.1168b, 6-8) afirmavam que a amizade

\footnotetext{
${ }^{36}$ Cf. Chiron, 1993, p. XCVII. Um exemplo dessa aplicação aos mais diversos tipos de discurso nos é dado por Dionísio de Halicarnasso, em Antiguidades Romanas, I, 1,3-4: hápantes nomízousin eikónas eînai tềs hekástou psykhềs ("todos consideram que os discursos são imagens da alma de cada um”). Tradução nossa. Para uma edição do texto grego, cf. Cary, 2005, p. 4.

${ }^{37}$ Cf. Chiron, 1993, p. XCVII.
} 
requer o compartilhamento de todas as coisas entre homens iguais, social e moralmente", mas, diante de um impedimento de estarem juntos, as cartas amigáveis (philikaî) serviriam como um "substituto adequado para o verdadeiro companheirismo". ${ }^{38}$

Ademais, podemos também nos reportar aqui àquele momento da educação ao qual a epistolografia fora associada, a que nos referimos antes. Schenkeveld teria, então, destacado que o tratado de Théon "classifica sob o gênero da prosōpooía, que alhures é chamada de êthopopoía, as espécies de consolação, exortação e aquela das cartas" e que o de Nicolau afirma que o "progýmnasma é útil ao treinamento para escrita de cartas, porque o estudante tem de considerar ambos: o caráter do remetente e aquele do destinatário". 39

Ora, embora não seja possível afirmar que essas obras, ao certo, mais tardias, reflitam uma situação que poderia ser subjacente à reflexão de Demétrio, se for este o caso, é de se supor que o autor do $\mathrm{PH}$ esteja aprofundando uma discussão elementar, e corrobora com isso o fato de que suas considerações vão muito além de uma exposição meramente descritiva e com uma finalidade puramente prática.

Então, pensando a epistolografia enquanto uma mostra de amizade, marcada pela simplicidade de assunto e palavras, juntamente com a capacidade de expressar o caráter (tò êthikón), como enfatizou Chiron, Demétrio apresenta-nos a faculdade que possui um estilo sem ornamento de revelar diretamente aquele que o utiliza, não mais com uma finalidade de convencimento, de despertar simpatia a partir de uma sentença, mas para instaurar uma relação mais íntima entre os seres. ${ }^{40}$

Assim também, embora as cartas, como vimos, apresentem um grau maior de elaboração quando comparadas ao diálogo, a exemplo deste último, elas mantêm a simplicidade no estilo como característica essencial, sobretudo para a manifestação da amizade. Isso inclui, além do emprego das palavras simples mencionadas no parágrafo supracitado, a breve exposição em um modo de se expressar sem pompa ${ }^{41}$ e com uma sintaxe mais livre. ${ }^{42}$

Simplicidade que, também vimos, deve ser extensiva ao assunto,

\footnotetext{
${ }^{38}$ Cf. Stowers, 1986, p. 58. O autor discorre, a seguir, sobre o manual atribuído ao autor homônimo do PH, o Týpoi epistolikoí, o qual anuncia, justamente, as cartas de amizade como o primeiro tipo. Acerca dessa questão, cf. De La Torre, La epistolografía griega, p. 34.

${ }^{39}$ Cf. Schenkeveld, 2000, p. 45.

${ }^{40}$ Cf. Chiron, 1993, p. XCVII.

${ }^{41} \int 228$.

${ }^{42} \ 229$.
} 
o que, segundo o autor do $P H$, remonta à própria obra de Aristóteles, conforme se verifica no parágrafo 230 :

Mas é preciso saber que não apenas o estilo, mas também certos assuntos são apropriados a uma carta. Aristóteles, por exemplo, o qual parece ter sido o mais bem sucedido no gênero epistolar, disse: E não te escrevo isso, pois não é apropriado a uma carta.

Por conseguinte, um sofisma, um discurso de ciências naturais, máximas, exortações, nada disso, enfim, seria conveniente em uma carta. Mas não significa que não se admita, na carta, uma sabedoria (sophós); nesse caso, ela viria justamente dos provérbios, por serem populares e conhecidos, conforme se registra no parágrafo 232:

Sem dúvida, a sua beleza está nas caras mostras de amizade e nos provérbios, que lhe são frequentes. E que seja apenas essa a sua sabedoria, porque o provérbio é algo popular e conhecido; já quem profere máximas e exortações não parece falar por meio de uma carta, mas sim de um artifício.

Mais ainda, a par dessa nítida tentativa de dissociar as cartas da filosofia, no parágrafo seguinte pode-se inferir uma tendência a discerni-la também dos demais discursos, ao menos se pensarmos na divisão proposta por Aristóteles no tratado Da interpretação. Isso porque, na passagem do $P H$ em questão, a carta, em virtude da simplicidade estilística, é aproximada da demonstração (apódeixis), a qual, segundo a concepção aristotélica, seria característica, justamente, do discurso declarativo (apophantikós), que, por sua vez, como bem lembrou Brandão, aparece, naquele tratado de Aristóteles (4, 17a 3), discriminado dos gêneros poéticos e retóricos. ${ }^{43}$

Mais do que isso, retomando o que nos diz o helenista, Aristóteles, ao propor essa divisão entre o discurso apofântico e aqueles que seriam próprios dos dois referidos gêneros - com relação aos quais não se investigaria apenas o lógos (pois a léxis tem uma função indispensável) —, estaria admitindo uma modalidade de discurso com léxis em grau

\footnotetext{
${ }^{43}$ Cf. Brandão, Lógos e léxis na "Retórica" de Aristóteles. Disponível em: $<<$ http:// www.letras.ufmg.br/jlinsbrandao/JLB_Logos_Lexis_Retor_Arist.pdf $>>$ Acesso em: março 2009 p. 11. Não confundamos o termo léxis, tomado aqui segundo uma concepção aristotélica, com aquela do $P H$.
} 
zero. ${ }^{44}$ Sendo assim, poderíamos, então, voltando à passagem de Demétrio, considerar a carta, em alguma medida, como um discurso com um grau de léxis, se não zero, pelo menos próximo disso, cuja finalidade, no caso, seria a de revelar o máximo do caráter de quem escreve, manifestando também o mais sincero sentimento de amizade.

E, ao certo, só se pode abdicar dessa simplicidade, em algum grau, nas cartas endereçadas a cidades e a reis, que teriam um estilo um pouco mais elevado, embora, mesmo neste caso, Demétrio admita a elevação, contanto não descaracterize o estilo epistolar, simples em essência, a ponto de cartas como a VII de Platão ou as de Aristóteles a Alexandre tornaremse, verdadeiramente, tratados filosóficos. ${ }^{45}$

Contudo, apesar de a simplicidade do estilo ser indicada, a todo instante, como o principal atributo da epistolografia, ao final de suas considerações, Demétrio, de modo até mesmo inesperado, conclui, no parágrafo 235:

Em suma, no que diz respeito ao estilo, a carta deve conter uma mistura destes dois tipos: o estilo da graça e o simples.

Ora, em nenhum outro momento da passagem referente às cartas, o autor do $P H$ destaca a presença do elemento estilístico especificamente ligado à graça (kháris) e isso provoca, no mínimo, algum estranhamento.

Grube, de modo não muito claro, atribui essa graça à expressão de amizade característica da carta, enviada, conforme vimos, como um presente ao destinatário, e que mereceria, segundo o autor, ainda "maior atenção por parte de seu remetente, cujo caráter inevitavelmente ela reflete"; concluindo ele que: "o próprio estilo epistolar, então, é basicamente uma admissão de elegância, e pode-se dizer que a carta requeira uma mistura dos estilos simples e elegante". ${ }^{46}$

Chiron, por outro lado, observou que, geralmente, Demétrio encontra, nas cartas de Aristóteles, dois aspectos que recomenda: simplicidade familiar e humor. E, assim, explicar-se-ia a situação do gênero

\footnotetext{
${ }^{44}$ Cf. Brandão, Lógos e léxis na "Retórica" de Aristóteles, p. 11.

${ }^{45}$ \ 234. Acerca da possível conexão com o propósito de formação moral do orador, a que nos referimos antes, Schenkeveld se indaga: Is he referring to real letters to be written to real kings and governments, or is he talking about fictional letters? Both interpretations may be valid (Schenkeveld, 2001, p. 45).

${ }^{46}$ Cf. Grube, 1961, p. 29. Para o estilo em questão optamos por "estilo da graça”, justamente, pela imprecisão do sentido do termo kháris, que ora se refere à graciosidade, elegância, ora à comicidade.
} 
epistolar, no meio do caminho, entre a simplicidade e a graça. ${ }^{47} \mathrm{E}$, ao certo, a despeito de algumas ressalvas, essa opinião parece explicar melhor a presença do estilo ligado à kháris na epistolografia.

Vejamos um exemplo que teria sido extraído de uma correspondência de Aristóteles e, então, associado ao elemento da graça: o fr. 669 Rose considerado como um resquício de uma carta a Antípater,$-{ }^{48}$ citado no parágrafo 29, em razão da igualdade fônica entre os colos, a qual seria responsável pela graça (kháris) do enunciado:

Quando Aristóteles diz: Eu vim de Atenas para Estagira por causa do rei grandioso; de Estagira para Atenas, por causa do frio grandioso. Se tirares, então, o segundo grandioso, irás tirar também a graça.

De fato, em um primeiro momento, essa (kháris) encontra-se, de algum modo, relacionada com a grandiloquência. Com efeito, se nos reportarmos ao parágrafo 128 , poderemos pensar em associá-la àquelas graças dos poetas, que estariam próximas de um estilo mais elevado. No entanto, se atentarmos bem para o parágrafo que precede o acima reproduzido, veremos que Demétrio sugere, sobretudo no provérbio tò en penthoûsi paizein (brincar na dor), que os chamados colos homeoteleutos estariam mais próximos de uma brincadeira.

Nesse sentido, se verificarmos, então, as ocorrências do termo que aqui define essa "brincadeira", bem como de seus derivados — paízein, paízōn, paígnion, paignía e paidiá —, veremos que eles se aplicam a situações em que a comicidade, em maior ou menor escala, está sempre presente. ${ }^{49}$ Inclusive, no parágrafo 143, o termo paígnion (em sua forma neutra plural) insere-se na discussão a respeito da kháris proveniente do vocabulário, encontrando-se, na ocasião, estreitamente relacionado com a comédia e o drama satírico; além dessa passagem, destaca-se ainda a do parágrafo 171, em que o termo paignía associa-se, de forma ainda mais direta, àquele tipo de kháris ligado ao riso (tò géloion).

Mas, apesar disso, não parece possível comprovar a associação do fragmento de Aristóteles com o cômico. De qualquer modo, sua outra ocorrência, no parágrafo 154 - que possui, aliás, uma construção muito

\footnotetext{
${ }^{47}$ Cf. Chiron, 1993, p. XCVIII.

${ }^{48}$ Cf. Chiron, 1993, p. 92 (n. 46).

${ }^{49}$ Cf. $\int 120,130,143,171,259$.
} 
parecida com a do 29 - , fornece também um indício dessa tendência de leitura da passagem pelo viés cômico. A frase de Aristóteles encontra-se, pois, neste caso, entremeada a outras relacionadas, mais propriamente, com a kháris ligada ao cômico.

Ainda que não seja possível, com isso, confirmar a referida associação, pelo menos nota-se uma tendência de leitura por parte de Demétrio, tendência que pode confirmar-se, sobretudo, se examinarmos as ocorrências do termo (kháris) quando associado ao estagirita. Constataremos, pois, que o elemento do humor não só está mais presente, como aparece nelas de forma mais contundente, enquanto que aquela (kháris) ligada mais precisamente ao que chamamos de "graciosidade" (eúkharis) é indicada, uma única vez, e sem muito destaque, no parágrafo 157 , a respeito da conhecida fábula da águia contada na História dos Animais.

Recordemos o próprio parágrafo 128, que introduz as reflexões concernentes ao estilo elegante, distinguindo os dois tipos de graça. Nessa ocasião, Aristóteles é tomado como modelo do emprego das graças mais comuns e mais cômicas, que se assemelham a escárnios, sendo designado ao lado de Sófron e Lísias, cujo exemplo que segue é, aliás, de um humor sarcástico. Também no parágrafo 164 - retomando, ao certo, a citação do parágrafo 144, em que o peripatético é lembrado pela graça proveniente 'do emprego de uma palavra comum' (ex idiōtikô̂ dè onómatos) — Aristóteles é mencionado, na discussão acerca dos dois tipos de graça, mais uma vez, associado, especificamente, à kháris ligada ao riso (tò géloion).

Logo, a justificativa dada por Chiron para a presença do estilo da graça na epistolografia parece, de fato, fazer mais sentido do que a proposta de Grube, ao menos se levarmos em conta as ocorrências no tratado das menções ao traço cômico do estagirita, o qual, é bom lembrar, teria exercido uma influência decisiva na passagem do $\mathrm{PH}$ a que nos referimos aqui.

Mas, além disso, se examinarmos, ainda, com um pouco mais de cuidado, os elementos estilísticos enumerados em tal passagem, iremos perceber que há, pelo menos, um deles que possui uma relação bem próxima com a kháris ligada ao cômico. Trata-se do provérbio (paroimía), apontado, como vimos, no parágrafo 232 , como um elemento recorrente nas cartas.

Se voltarmos, pois, ao parágrafo 156, onde se pode ler que, "por natureza, o provérbio é um assunto que tem graça" (phýsei gàr kharien prâgmá esti hē paroimía), veremos que os exemplos que nos oferece Demétrio sobretudo o segundo deles — revelam situações em que o traço cômico é evidente. Além do que, vale lembrar, a justificativa para a sua frequência nas cartas é exatamente o fato de ser popular (dēmotikós) e conhecido (koinós), características que se encontram, em outras ocasiões em estreita relação 
com a graça ligada à comicidade.

Quanto à primeira das características indicadas, há mais uma ocorrência, no parágrafo 177, e, nela, o termo dēmotikós, relaciona-se diretamente com a comédia, caracterizando o dialeto ático e se adequando, então, ao humor tão caro ao gênero. Já a segunda, definida pelo termo koinós, relaciona-se com a kháris em outras duas ocorrências. No parágrafo 157, o termo que a define, de fato, parece estar associado mais propriamente àquela graça que denominamos "graciosidade" (eúkharis); contudo, essa relação não é tão direta nem tão contundente quanto a que se observa no parágrafo 164, em que se diz claramente que "o risível resulta de palavras comuns e mais conhecidas" (tò géloion kaì onomátōn estìn eutelòn kaì koinotérōn), lembrando-se que o exemplo seguinte é justo uma citação de Aristóteles.

Sendo assim, pela análise tanto das ocorrências das menções ao cômico em Aristóteles, quanto de um conjunto de elementos da passagem que se reportam a outros momentos do $P H$, é razoável supor que, nessa derradeira afirmação sobre o estilo epistolar, Demétrio esteja admitindo alguma dose de humor nas cartas, conquanto não comprometa a simples e sincera manifestação de amizade.

\section{Referências}

BOMPAIRE, J. Lucien Écrivan: imitation et création. Paris: Les Belles Lettres, 2000. BRANDÃO, J. L. Lógos e léxis na "Retórica" de Aristóteles. Disponível em: $<<$ http://www.letras.ufmg.br/jlinsbrandao/JLB_Logos_Lexis_Retor_Arist. pdf $>>$ Acesso em: março 2009.

CARY, E. Dionysius of Halicarnassus: Roman antiquities. Vol. 1. Cambridge, Mass./ London: Harvard University Press, 2005.

CHIRON, P. Un rhéteur méconnu - Démétrios (Ps.- Démétrios de Phalère): essai sur les mutations de la théorie du style à l'époque hellénistique. Paris: Librairie Philosophique J. Vrin, 2001.

CHIRON, P. Démétrios: «Du style». Paris: Les Belles Lettres, 1993.

CLASSEN, C. J. Rhetoric and literary criticism: their nature and their functions in Antiquity. Mnemosyne, Leiden, vol. XLVIII, p. 513-535, 1995.

DE LA TORRE, E. S. La epistolografía griega. < < http://interclassica.um.es/var/ plain/storage/original/application/a757900df19260b09f9e81f774adc1b6.pdf $>>$ Acesso em: setembro 2009.

de FREITAS, G. A. "Sobre o estilo" de Demétrio: um olhar crítico sobre a Literatura Grega (tradução e estudo introdutório do tratado). Dissertação de mestrado inédita. Belo Horizonte: FALE-UFMG, 2011 (177f). 
GRUBE, G. M. A. The Greek and Roman critics. Indianapolis: Hackett Publishing Company, Inc., 1995, p. 110-121.

GRUBE, G. M. A. A Greek critic: Demetrius "On style”. Toronto: University of Toronto Press, 1961.

INNES, D. C. Demetrius: “On style” (in. Aristotle, v. XXIII). Cambridge, Mass./ London: Harvard University Press, 2005.

INNES, D. C. Reviewed work(s): studies in Demetrius "On style" by Dirk Marie Schenkeveld. The classical review, new series, Cambridge, vol. XVI, n. 3, p. 315-317, dec. 1966.

KENNEDY, G. A. Classical Rhetoric $\mathcal{E}$ its Christian $\mathcal{E}$ secular tradition from ancient to modern times. $2^{\text {nd }}$ ed., rev. and enl. Chapel Hill: University of North Carolina Press, 1999, p. 127-136.

KENNEDY, G. A. A new history of classical rhetoric. Princeton, N.J.: Princeton University Press, 1994, p. 81-101.

KENNEDY, G. Reviewed work(s) - A Greek critic: Demetrius “On style” by G. M. A. Grube. The American journal of philology, Baltimore, vol. LXXXIV, n. 3, p. 313-317, jul., 1963a.

KENNEDY, G. The Art of Persuasion in Greece. Princeton: Routledge \& Kegan Paul, 1963b.

LÓPEZ, J. G. Demetrio, Sobre el Estilo; 'Longino', Sobre lo Sublime. Madrid: Editorial Gredos, 1996.

MARROU, H.-I. História da educação na Antiguidade. Trad. Mário Leônidas Casanova. $2^{\mathrm{a}}$ ed. São Paulo: EPU, 1975.

MOXON, T. A. "On style”: Demetrius (in Poetics). London: Everyman's Library, 1963.

MORPURGO-TAGLIABUE, G. Demetrio: dello stile. Roma: Edizioni dell'Ateneo, 1980.

PERNOT, L. La Rhétorique dans l'Antiquité. Paris: Librairie Génerale Française, 2000.

ROBERTS, W. R. Demetrius "On Syle", the Greek text of Demetrius "De Elocutione" edited after the Paris manuscript. With introduction, translation, facsimiles, etc. Cambridge: Cambridge University Press, 2010 (1902).

ROBERTS, W. R. The Greek words for "style" (with special reference to

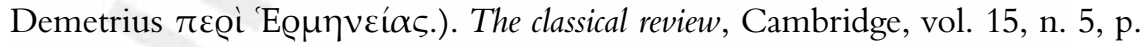
252-255, jun. 1901.

RUSSELL, D. A. Greek declamation. Cambridge: Cambridge University Press, 1983.

SCHENKEVELD, D. M. The intended public of Demetrius's "On style": the place of the treatise in the Hellenistic educational system. Rhetorica, Leiden, vol. XVIII, n. 1, p. 29-48, 2000.

SCHENKEVELD, D. M. Démétrios by Pierre Chiron. Mnemosyne, forth series, vol. 7, fasc. 3, p. 400-411, jun. 1994. 